\title{
Front Matter: Volume 7693
}

, "Front Matter: Volume 7693," Proc. SPIE 7693, Unattended Ground, Sea, and Air Sensor Technologies and Applications XII, 769301 (24 May 2010); doi: $10.1117 / 12.864062$

SPIE Event: SPIE Defense, Security, and Sensing, 2010, Orlando, Florida, United SPIE. States 


\section{PROCEEDINGS OF SPIE}

\section{Unattended Ground, Sea, and Air Sensor Technologies and Applications XII}

Edward M. Carapezza

Editor

5-8 April 2010

Orlando, Florida, United States

Sponsored and Published by

SPIE

Volume 7693 
The papers included in this volume were part of the technical conference cited on the cover and title page. Papers were selected and subject to review by the editors and conference program committee. Some conference presentations may not be available for publication. The papers published in these proceedings reflect the work and thoughts of the authors and are published herein as submitted. The publisher is not responsible for the validity of the information or for any outcomes resulting from reliance thereon.

Please use the following format to cite material from this book:

Author(s), "Title of Paper," in Unattended Ground, Sea, and Air Sensor Technologies and Applications XII, edited by Edward M. Carapezza, Proceedings of SPIE Vol. 7693 (SPIE, Bellingham, WA, 2010) Article CID Number.

ISSN 0277-786X

ISBN 9780819481573

Published by

SPIE

P.O. Box 10, Bellingham, Washington 98227-0010 USA

Telephone +1 3606763290 (Pacific Time) · Fax +1 3606471445

SPIE.org

Copyright (C) 2010, Society of Photo-Optical Instrumentation Engineers

Copying of material in this book for internal or personal use, or for the internal or personal use of specific clients, beyond the fair use provisions granted by the U.S. Copyright Law is authorized by SPIE subject to payment of copying fees. The Transactional Reporting Service base fee for this volume is $\$ 18.00$ per article (or portion thereof), which should be paid directly to the Copyright Clearance Center (CCC), 222 Rosewood Drive, Danvers, MA 01923. Payment may also be made electronically through CCC Online at copyright.com. Other copying for republication, resale, advertising or promotion, or any form of systematic or multiple reproduction of any material in this book is prohibited except with permission in writing from the publisher. The CCC fee code is 0277-786X/10/\$18.00.

Printed in the United States of America.

Publication of record for individual papers is online in the SPIE Digital Library.

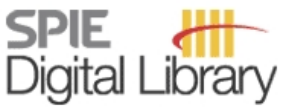

SPIEDigitalLibrary.org

Paper Numbering: Proceedings of SPIE follow an e-First publication model, with papers published first online and then in print and on CD-ROM. Papers are published as they are submitted and meet publication criteria. A unique, consistent, permanent citation identifier (CID) number is assigned to each article at the time of the first publication. Utilization of CIDs allows articles to be fully citable as soon they are published online, and connects the same identifier to all online, print, and electronic versions of the publication. SPIE uses a six-digit CID article numbering system in which:

- The first four digits correspond to the SPIE volume number.

- The last two digits indicate publication order within the volume using a Base 36 numbering system employing both numerals and letters. These two-number sets start with 00, 01, 02, 03, 04, $05,06,07,08,09,0 A, 0 B \ldots 0 Z$, followed by 10-1Z, 20-2Z, etc.

The CID number appears on each page of the manuscript. The complete citation is used on the first page, and an abbreviated version on subsequent pages. Numbers in the index correspond to the last two digits of the six-digit CID number. 


\section{Contents}

vii Conference Committee
xi Introduction

\section{LASER AND OTHER TECHNOLOGY}

769303 Engineering rare-earth-doped heavy metal oxide glasses for 2-5 $\mu \mathrm{m}$ lasers [7693-02] B. D. O. Richards, A. Jha, Univ. of Leeds (United Kingdom); V. Dorofeev, Institute of Chemistry of High-Purity Substances (Russian Federation); T. Manzur, Naval Undersea Warfare Ctr. (United States)

769307 Distributed optical microsensors for hydrogen leak detection and related applications [7693-06]

S. R. Hunter, Oak Ridge National Lab. (United States); J. F. Patton, M. J. Sepaniak, The Univ. of Tennessee (United States); P. G. Datskos, Oak Ridge National Lab. (United States) and The Univ. of Tennessee (United States); D. B. Smith, Oak Ridge National Lab. (United States)

769308 Chalcogenide fiber for mid-infrared transmission and generation of laser source [7693-07] F. Chenard, R. A. Kuis, IRflex Corp. (United States)

\section{EO/IR TECHNOLOGY FOR UGS}

7693 OC Next generation nanostructure-based EO/IR focal plane arrays for unattended ground sensor applications [7693-11]

A. K. Sood, R. A. Richwine, Y. R. Puri, Magnolia Optical Technologies, Inc. (United States); T. Manzur, Naval Undersea Warfare Ctr. (United States); N. K. Dhar, D. L. Polla, Defense Advanced Research Projects Agency (United States); P. S. Wijewarnasuriya, U.S. Army Research Lab. (United States); Y. Wei, J. Zhou, C. Li, Z. L. Wang, Georgia Institute of Technology (United States); G. Fernandes, J. M. J. Xu, Brown Univ. (United States)

7693 OG High-resolution streaming video integrated with UGS systems [7693-15] M. Rohrer, McQ, Inc. (United States)

\section{SIGNAL PROCESSING AND SENSOR FUSION}

$7693 \mathrm{OH}$ Sensor and information fusion for improved hostile fire situational awareness [7693-16] M. V. Scanlon, W. D. Ludwig, U. S. Army Research Lab. (United States)

7693 OK Development of an infrared imaging classifier for UGS [7693-19]

B. D'Agostino, M. McCormack, B. Steadman, Textron Defense Systems (United States) 
7693 OL A learning-based autonomous driver: emulate human driver's intelligence in low-speed car following [7693-20]

J. Wei, Carnegie Mellon Univ. (United States); J. M. Dolan, Carnegie Mellon Univ. (United States) and The Robotics Institute, Carnegie Mellon Univ. (United States); B. Litkouhi,

GM-CMU Autonomous Driving Collaborative Research Lab., General Motors Corp. (United States)

7693 OM Planning to fail: using reliability to improve multirobot task allocation [7693-21]

S. B. Stancliff, Energetics Technology Ctr. of Southern Maryland (United States); J. M. Dolan, Carnegie Mellon Univ. (United States)

$7693 \mathrm{ON} \quad$ Learning a detection map for a network of unattended ground sensors [7693-22]

M. W. Koch, H. D. Nguyen, Sandia National Labs. (United States)

769300 Assessment of a linear pyroelectric array sensor for profile classification [7693-23]

J. B. Brown, S. Chari, The Univ. of Memphis (United States); J. Hutchison, J. Gabonia, U.S. Army

Night Vision \& Electronic Sensors Directorate (United States); E. Jacobs, The Univ. of Memphis (United States)

PERIMETER SURVEILLANCE AND SECURITY

7693 OS Unattended monitoring of suspicious behavior for route surveillance [7693-28]

R. Schoemaker, R. Sandbrink, G. van Voorthuijsen, TNO Defence, Security and Safety (Netherlands)

7693 OT Efficient deployment of fiber-optic cable seismic sensors [7693-29]

N. C. Rowe, Naval Postgraduate School (United States)

MARITIME UGS AND APPLICATIONS

7693 OW Edge systems in the deep ocean (Invited Paper) [7693-32]

A. Coon, Defense Advanced Research Projects Agency (United States); S. L. Earp, Multisensor Science, LLC (United States)

7693 0X Keeping our waterways safe by equipping commercial vessels with appropriate sensor suites to enable pervasive surveillance of coastal and inland waterborne commercial traffic [7693-33]

T. Feeley, J. Lavoie, Rite-Solutions, Inc. (United States)

7693 OY Semi-fuel cell studies for powering underwater devices: integrated design for maximized net power output [7693-34]

A. M. Cardenas-Valencia, R. T. Short, L. Adornato, L. Langebrake, SRI International (United States)

769310 An optimization approach to generate robust tradeoffs for the configuration of passive sensor fields against moving targets [7693-36]

T. A. Wettergren, Naval Undersea Warfare Ctr. (United States) 
769311 Time-domain classification of humans using seismic sensors [7693-38]

S. Schumer, U.S. Army Research, Development and Engineering Command (United States)

769312 Development of acoustic sniper localization methods and models [7693-39]

D. Grasing, B. Ellwood, U.S. Army Research, Development and Engineering Command (United States)

769313 Sensitive optical atomic magnetometer based on nonlinear magneto-optical rotation [7693-40]

C. Hovde, Southwest Sciences, Inc. (United States); B. Patton, E. Corsini, Univ. of California, Berkeley (United States); J. Higbie, Bucknell Univ. (United States); D. Budker, Univ. of California, Berkeley (United States)

\section{BIO-INSPIRED TECHNOLOGY FOR UGS}

7693 1A BackyardNet: distributed sensor network powered by terrestrial microbial fuel cell technology [7693-47]

K. G. Cooke, M. O. Gay, S. E. Radachowsky, J. J. Guzman, M. A. Chiu, Trophos Energy, Inc. (United States)

7693 1B A high-throughput label-free cell-based biosensor (CBB) system [7693-48]

F. Xu, S. Moon, Brigham and Women's Hospital, Harvard Medical School (United States);

E. Hefner, Brigham and Women's Hospital, Harvard Medical School (United States) and Massachusetts Institute of Technology (United States); T. Beyazoglu, A. E. Emre, Brigham and Women's Hospital, Harvard Medical School (United States); T. Manzur, Naval Undersea Warfare Ctr. (United States); U. Demirci, Brigham and Women's Hospital, Harvard Medical School (United States) and Harvard-Massachusetts Institutes of Technology Health Sciences and Technology (United States)

\section{SENSOR NETWORKS AND COMMUNICATIONS}

7693 ID Seismic-acoustic communication for UGS [7693-50]

J. Cechak, Univ. of Defence (Czech Republic)

$7693 \mathrm{IF}$ Atmospheric transmission at $\sim 1.55 \mu \mathrm{m}$ for free-space optical communication [7693-53] J. Zeller, T. Manzur, Naval Undersea Warfare Ctr. (United States)

$76931 \mathrm{G}$ Exploratory community sensing in social networks [7693-54]

A. Khrabrov, G. Stocco, G. Cybenko, Dartmouth College (United States)

PANEL DISCUSSION: UGS - FUTURE TECHNOLOGIES AND CHALLENGES

$76931 \mathrm{~J}$ Advanced unattended sensors and systems: state of the art and future challenges (Invited Paper) [7693-57]

J. H. McQuiddy, McQ, Inc. (United States) 
UNATTENDED SENSOR SYSTEMS

7693 IL Enhanced technologies for unattended ground sensor systems [7693-59]

D. C. Hartup, L-3 Communications Nova Engineering (United States)

$76931 \mathrm{M}$ UGS-technology-driven application expansion [7693-60]

J. H. McQuiddy, McQ, Inc. (United States)

769310 Affordable next-generation UGS development and testing [7693-62]

M. Winston, D. Egerton, J. McQuiddy, B. Jones, McQ, Inc. (United States)

7693 1Q SCORPION II persistent surveillance system update [7693-64]

M. Coster, J. Chambers, Northrop Grumman-Xetron (United States)

7693 IR A roadmap to truly disposable unattended ground sensor (UGS) systems [7693-65]

B. M. Jones, McQ, Inc. (United States)

Author Index 


\title{
Conference Committee
}

\author{
Symposium Chair \\ Michael T. Eismann, Air Force Research Laboratory (United States) \\ Symposium Cochair \\ William Jeffrey, HRL Laboratories, LLC (United States) \\ Conference Chair
}

Edward M. Carapezza, University of Connecticut and DARPA

(United States)

Program Committee

Jacques Bédard, Defence Research and Development Canada (Canada)

John G. Blitch, ARACAR: Alliance for Robot Assisted Crisis Assessment and Response (United States)

John C. Carrano, Carrano Consulting (United States)

Christina J. Deckard, Space and Naval Warfare Systems Center, San Diego (United States)

Daniel D. Desjardins, Air Force Research Laboratory (United States)

John S. Eicke, U.S. Army Research Laboratory (United States)

Alan J. Gray, Defence Science and Technology Laboratory (United Kingdom)

Jeffrey R. Heberley, U.S. Army Armament Research, Development and Engineering Center (United States)

Todd M. Hintz, Space \& Naval Warfare Systems Command SPAWARSYSCEN (United States)

Myron E. Hohil, U.S. Army Research, Development and Engineering Command (United States)

Ivan Kadar, Interlink Systems Sciences, Inc. (United States)

George McNamara, Naval Undersea Warfare Center (United States)

Tariq Manzur, Naval Undersea Warfare Center (United States)

Frank Patton, Defense Advanced Research Projects Agency (United States)

Huub A. J. M. van Hoof, TNO Defence, Security and Safety (Netherlands)

Graeme P. van Voorthuijsen, TNO Defence, Security and Safety (Netherlands) 
Session Chairs

$1 \quad$ Laser and Other Technology

John M. Dolan, Carnegie Mellon University (United States)

Tariq Manzur, Naval Undersea Warfare Center (United States)

2 EO/IR Technology for UGS

John M. Dolan, Carnegie Mellon University (United States)

Myron E. Hohil, U.S. Army Research, Development and Engineering Command (United States)

2 Signal Processing and Sensor Fusion

John M. Dolan, Carnegie Mellon University (United States)

Myron E. Hohil, U.S. Army Research, Development and Engineering Command (United States)

4 Air/Ground Collaboration

Myron E. Hohil, U.S. Army Research, Development and Engineering Command (United States)

5 Perimeter Surveillance and Security

Sachi V. Desai, U.S. Army Armament Research, Development and Engineering Center (United States)

6 Maritime UGS and Applications

Sachi V. Desai, U.S. Army Armament Research, Development and Engineering Center (United States)

George McNamara, Naval Undersea Warfare Center (United States)

Tariq Manzur, Naval Undersea Warfare Center (United States)

7 Acoustic, Magnetic, and Seismic Sensing

Sachi V. Desai, U.S. Army Armament Research, Development and Engineering Center (United States)

Myron E. Hohil, U.S. Army Research, Development and Engineering Command (United States)

$8 \quad$ Bio-Inspired Technology for UGS

Myron E. Hohil, U.S. Army Research, Development and Engineering Command (United States)

Daniel Lehrfeld, Blue Marble Group, LLC (United States)

9 Sensor Networks and Communications

Myron E. Hohil, U.S. Army Research, Development and Engineering Command (United States)

Daniel Lehrfeld, Blve Marble Group, LLC (United States) 
10 Panel Discussion: UGS - Future Technologies and Challenges

Myron E. Hohil, U.S. Army Research, Development and Engineering Command (United States)

11 Unattended Sensor Systems

Myron E. Hohil, U.S. Army Research, Development and Engineering Command (United States)

12 Ground Surveillance System I: Joint Session with Conference 7666

Daniel Lehrfeld, Blue Marble Group, LLC (United States)

13 Ground Surveillance System II: Joint Session with Conference 7666 Daniel Lehrfeld, Blue Marble Group, LLC (United States)

14 Counter Sniper: Joint Session with Conference 7666

Myron E. Hohil, U.S. Army Research, Development and Engineering Command (United States)

15 Maritime and Port Surveillance I: Joint Session with Conference 7666 Han Q. Le, University of Houston (United States)

George McNamara, Naval Undersea Warfare Center (United States)

16 Maritime and Port Surveillance II: Joint Session with Conference 7666 Han Q. Le, University of Houston (United States)

George McNamara, Naval Undersea Warfare Center (United States) 
Downloaded From: https://www.spiedigitallibrary.org/conference-proceedings-of-spie on 25 Apr 2023

Terms of Use: https://www.spiedigitallibrary.org/terms-of-use 


\section{Introduction}

The interest in unattended sensor technologies and applications has dramatically increased over the past several years. Systems are being developed in support of military, homeland security, intelligence, law enforcement, physical security, and environmental monitoring applications around the world. Government agencies are making significant investments to develop improved unattended sensors and sensor networks. Recently the United States and other countries have significantly increased the use of unattended ground, sea, and air sensors for homeland security applications, such as land border and coastal shore monitoring. This SPIE conference series is devoted to papers on recent technological advancements in unattended ground, sea, and air sensor technologies and applications

The conference included four keynote/invited talks and 85 technical paper presentations organized into 11 technical sessions covering recent advances in Laser, EO/IR, Signal Processing, Sensor Fusion, Air/Ground Collaboration, Perimeter Surveillance and Security, Maritime UGS and Applications, Bio-Inspired Technology for UGS, Acoustic, Magnetic, and Seismic Sensing, Sensor Networks and Communications, and five additional joint sessions with Sensors and C3I Technologies for Homeland Security and Homeland Defense (Conference 7666) on Ground Surveillance, Counter Sniper, and Maritime and Port Surveillance Systems.

The following five keynote/invited presentations were given and we sincerely thank all of the following speakers for very stimulating and relevant presentations:

1) "UUV autonomy considerations for extended reach of naval platforms" by Dr. P. J. Corriveau (Naval Undersea Warfare Center)

2) "Advanced distributed maritime sensors" by Dr. A. Coon (Defense Advanced Research Projects Agency)

3) "Nano-engineered chemical and biological sensors with unprecedented sensitivity based on SERS: opportunities and challenges" by Dr. M. Moskovits (University of California, Santa Barbara)

4) "Free-surface microfluidics for control of SERS hot-spot formation" by

Dr. C. D. Meinhart (University of California, Santa Barbara)

5) Bio-inspired networks for command and control Dr .J. P. Hespanha (University of California, Santa Barbara)

Additionally a special panel titled "Future Technologies and Challenges for Unattended Sensor Systems" was included in the program. The following four 
additional invited papers were presented during this panel discussion and we sincerely thank all of the following speakers for very stimulating and relevant presentations:

1)"Department of Homeland Security (DHS) Science and Technology Unattended Ground Sensor (UGS) focus areas and capabilities" by Dr. John Appleby (U.S. Department of Homeland Security)

2) "Future trends in MEMS and NEMS" by Dr. Panos Datskos (Oak Ridge National Laboratory)

3) "Advanced unattended sensors and systems: state of art and future challenges" by Dr. John McQuiddy (McQ Inc.)

4) "Future directions in sensor technologies" by Dr. Jennifer Ricklin (Lockheed Martin Corporation)

Thanks to those who prepared and presented the technical papers and for their contribution to a very successful meeting. The success of this conference is attributed to the participation of the commercial, university, and government research-and-development community as well as the organizing efforts of the diverse and talented program committee.

Thanks to our program committee members for their dedication, time and assistance in conference planning and organizing and especially to those members who were able to participate as session chairs including: Todd Hintz (Naval Space and Warfare Center), Myron Hohil (U.S. Army Research, Development and Engineering Command), Dan Lehrfeld (Blve Marble Group), Tariq Manzur (Naval Undersea Warfare Center), George McNamara (Naval Undersea Warfare Center), and Sachi Desai (U.S. Army Research, Development and Engineering Command).

Very special thanks to two of our program committee members who worked extra hard to help organize this challenging conference: Todd Hintz and Myron Hohil. We could not have had so successful a technical conference without their excellent help and dedication.

Finally, an extra special thanks to all of the conference attendees this year for your interest and enthusiasm. The conference was well attended this year, with a lot of interest in all the sessions. We hope the interest in this technology continues to grow, and that this conference will expand with even greater technical content and significance in future years. 